\title{
Fatores que promovem discordâncias entre fisco e contribuinte a respeito da comprovação de hedge
}

Factors to promote disagreement between tax authorities and taxpayers in regard to hedge validation

Factores que promueven desacuerdos entre autoridades tributarias y contribuyentes sobre la prueba de hedge

\section{Ralph Melles Sticca}

Mestre em Controladoria e Contabilidade pela Faculdade de Economia, Administração e Contabilidade de Ribeirão Preto - Universidade de São Paulo (FEA-RP/USP)

Professor dos cursos de MBA da Fundace Business School e Fundação Getúlio Vargas (FGV).

Endereço: Avenida Braz Olaia Acosta, no. 727, CJ. 607, Jardim Califórnia

CEP: 14.026-040 - Ribeirão Preto/SP - Brasil

E-mail: ralphsticca@usp.br

Telefone: (16) 3911-1419

\section{Sílvio Hiroshi Nakao}

Doutor e Livre-Docente em Contabilidade pela Universidade de São Paulo Professor Associado do Departamento de Contabilidade da FEA-RP/USP

Endereço: Av. Bandeirantes, 3900, Monte Alegre

CEP: 14.040-905 - Ribeirão Preto/SP - Brasil

E-mail:shnakao@usp.br

Telefone: (16) 3602-3919

Artigo recebido em 08/03/2013. Revisado por pares em 22/04/2013. Reformulado em 26/05/2013. Recomendado para publicação em 25/10/2013 por Sandra Rolim Ensslin (Editora Científica). Publicado em 15/12/2013. 


\title{
Resumo
}

O trabalho investiga fatores que promovem discordâncias entre Fisco e contribuinte na comprovação de hedge em operações financeiras, requisito legal para a dedutibilidade das perdas no cálculo do imposto sobre a renda. Estudo de caso em empresa exportadora autuada pela RFB em 2008 demonstrou que a comprovada exposição ao risco ex-ante de variação de preços de commodities e câmbio não foi suficiente para evitar o agravamento das perdas por sua indedutibilidade, graças à ausência de critérios gerenciais e contábeis padronizados, constatação corroborada por pesquisa documental e análise de conteúdo de decisões da RFB sobre o tema, de 1999 a 2010.

Palavras-chave: Tributação de hedge. Hedge em operações financeiras. Contabilidade de hedge.

\begin{abstract}
This paper investigates factors that cause disagreement between tax authorities and taxpayers in regard to hedge validation in financial operations, which is a legal requeriment for the deducibility of losses over the income tax. A case-study, which was carried out in an exporting company that had been fined by Receita Federal do Brasil in 2008, showed that the attested measure of exposure to the ex-ante risk of variation in commodity prices and in exchange was not enough to avoid the aggravation of losses given the non-deducibility of such measure. This is due to the lack of management criteria as well as the lack of accounting criteria standarts, which was corroborated in documentary research and content analysis over decisions made by the Receita Federal do Brasil on this issue from 1999 to 2010.
\end{abstract}

Keywords: Hedge funds. Hedge in financial operations. Hedge accounting.

\section{Resumen}

El trabajo investiga factores que promueven el desacuerdo entre las autoridades fiscales y los contribuyentes sobre la comprobación de hedge en las operaciones financieras, requisito legal para la deducibilidad de las pérdidas en el cálculo del impuesto sobre la renta. Caso de estudio en empresa exportadora actuada por la RFB en 2008 demostró que la exposición comprobada al riesgo ex-ante de variación de precios de commodities y de cambio no fue suficiente para evitar el aumento en las pérdidas por su carácter no deducible gracias a la ausencia de criterios contables y de gestión estandarizados, constatación corroborada por investigación documental y por análisis de contenido de las decisiones de la RFB sobre el tema desde 1999 hasta 2010.

Palabras clave: Tributación de hedge. Hedge en operaciones financieras. Contabilidad de hedge. 


\section{Introdução}

Shackelford e Shevlin (2001) destacam que a pesquisa acadêmica focada em tributos e teoria da agência é pouco desenvolvida, sugerindo a importância de estudos científicos que se propõem a debater a relação Fisco-contribuinte sob a abordagem dessa teoria, por exemplo, na comprovação da finalidade de hedge $e^{l}$ de operações financeiras com derivativos praticadas pelas companhias.

Milevsky e Prisman (1999) e Lien e Metz (2001), em trabalhos motivados pelas decisões da Corte Suprema (Supreme Court) dos Estados Unidos da América (EUA), nos casos "Corn Products" e "Arkansas Best", destacaram que os contratos futuros proveem uma ferramenta útil na gestão de riscos, pois, para reduzir seu risco, um hedger assume uma posição futura oposta à posição à vista (spot), esperando que os ganhos de uma posição compensem as perdas da outra, ressaltando, contudo, que a extensão desta compensação é influenciada diretamente por normas tributárias.

Por outro lado, assim como agilizam e propiciam maior segurança ao processo de negociação, instrumentos derivativos também permitem aos participantes do mercado especular, operar fora dos limites operacionais, manipular normas contábeis e realizar operações ilimitadamente alavancadas, ocasionando exposições excessivas não registradas nas demonstrações contábeis; o incentivo para que isso ocorra está diretamente relacionado com a possibilidade de obtenção de ganhos vultosos e em curto espaço de tempo, aproveitando-se de lacunas ou eventual má qualidade de regulamentação existente (CAPELLETTO; OLIVEIRA; CARVALHO, 2007).

Em relação ao Brasil, Lopes, Galdi e Lima (2011) destacam que como diversos normativos estabeleceram que perdas com operações com derivativos somente poderiam ter seus montantes deduzidos na apuração do lucro real quando estes fossem referentes a operações de hedge, torna-se essencial para a matéria tributária e o estudo acadêmico na área contábil definir o que é uma operação de hedge e como reconhecê-la, mensurá-la e evidenciála.

De fato, a legislação tributária brasileira (Lei n. 8.981/95) autoriza a dedutibilidade integral das despesas (perdas incorridas e prêmios pagos) com esse tipo de operação (hedge) na apuração do Imposto de Renda da Pessoa Jurídica (IRPJ) e da Contribuição Social sobre o Lucro Líquido (CSLL), afastando nesses casos a limitação imposta pela mesma legislação às operações financeiras em geral - para as quais as perdas somente são dedutíveis até o limite dos ganhos auferidos com as mesmas operações e no mesmo período.

Para tanto, a legislação tributária brasileira exige que a pessoa jurídica comprove que as operações financeiras se destinam exclusivamente à proteção contra riscos inerentes às oscilações de preço ou de taxas, sempre que o objeto do contrato negociado: (i) estiver relacionado com as atividades operacionais da pessoa jurídica; ou (ii) destinar-se à proteção de direitos ou obrigações da pessoa jurídica ${ }^{2}$, sem definir, contudo, quais controles internos devem ser elaborados, quais documentos devem ser apresentados pelo contribuinte ou quais declarações adicionais devem ser preenchidas e entregues à Secretaria da Receita Federal do Brasil (RFB).

\footnotetext{
${ }^{1}$ Ressalte-se que hedge é outro tema de destaque em trabalhos científicos nacionais e internacionais, só que com viés principalmente econômico ou contábil.

${ }^{2}$ Art. 77, § 1', "a" e "b" da Lei n. 8.981/95. 
Assim, a comprovação da natureza de hedge de operações financeiras não somente do ponto de vista fiscal, como também gerencial, financeiro e contábil, torna-se fundamental para assegurar o benefício da dedutibilidade das perdas em operações financeiras no cálculo do IRPJ (e da CSLL), pois, caso contrário, estas serão deduzidas como despesas na apuração contábil do resultado do exercício, porém serão adicionadas ao cálculo do Lucro Real (base de cálculo do IRPJ) e à base de cálculo da CSLL, sendo tributadas pela alíquota consolidada de $34 \%^{3}$, sem prejuízo da aplicação de multas de ofício de $75 \%$ a $150 \%$ do tributo devido, no caso de autuação fiscal ${ }^{4}$.

Nesse contexto, por ser exigida pela legislação tributária a comprovação do hedge para fins do benefício da dedutibilidade, compete ao Fisco (no caso a RFB) promover a auditoria dos demonstrativos e documentos apresentados pelo contribuinte que suportem a comprovação da natureza e hedge, sendo provável sua eventual discordância ou não aceitação, resultando em autuações fiscais que cobram o IRPJ e a CSLL sobre mencionadas despesas.

Com isso, este artigo se apóia na seguinte questão de pesquisa: quais são os fatores que promovem discordâncias entre Fisco e contribuinte a respeito da comprovação de hedge, especificamente em operações financeiras carreadas no âmbito do mercado financeiro e de capitais?

Para buscar responder a essa questão, a realização do estudo empírico foi composta por estudo de caso em empresa comercial exportadora autuada em 2008 em decorrência de mencionada dissonância de tratamento e por pesquisa documental e análise de conteúdo de decisões administrativas publicadas pela própria RFB sobre o assunto, de 1999 a 2010.

Tal estudo se torna relevante na medida em que também os contribuintes de países desenvolvidos como Canadá, Reino Unido e EUA enfrentam problemas em relação à comprovação de hedge e dedutibilidade de perdas de operações financeiras que praticam nos mercados à vista, futuros e de opção, em função de legislações ambíguas - conforme sugerem os estudos de Lien e Metz (2001) e Milevsky e Prisman (1999) -, tema este cada vez mais em discussão no Brasil, seja em função da convergência das normas contábeis locais com os guidelines internacionais (International Accounting Standards Board - IASB, conforme Lei n. 11.638/07), seja pelo desenvolvimento do comércio exterior brasileiro, ou ainda em razão do aumento no número de autuações fiscais sofridas pelas empresas em decorrência dessas operações financeiras.

Dessa forma, o trabalho está estruturado em: (i) revisão bibliográfica, em que são descritos os principais artigos e papers internacionais acerca dos temas comprovação de hedge, hedge accounting e tratamento das perdas de acordo com a legislação tributária vigente; (ii) metodologia de pesquisa, em que são descritos o tipo e as fases do estudo empírico realizado como base para fundamentação das análises e conclusões; (iii) estudo de caso, em que são discutidos os resultados encontrados a partir da execução do "protocolo de estudo de caso" e análise dos dados retornados; (iv) decisões administrativas sobre o tema, em que são apresentados os resultados da pesquisa documental/análise de conteúdo realizada em decisões administrativas da RFB sobre o tema "comprovação de hedge"; (v) conclusões; e (vi) referências.

\footnotetext{
3 Alíquota de $15 \%$ e alíquota adicional de $10 \%$ sobre o que ultrapassar os $\mathrm{R} \$ 20.000,00$ mensais, a título de IRPJ, e 9\% de CSLL.

${ }^{4}$ Art. 44 , I e $\S 1^{\circ}$ da Lei n. 9.430/96.
}

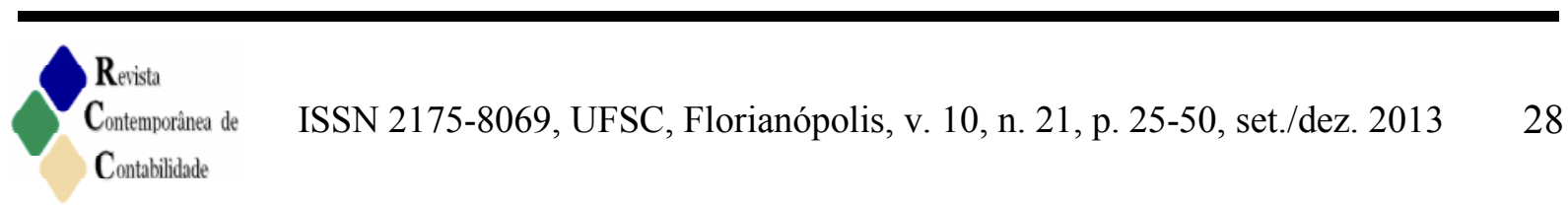




\section{Revisão Bibliográfica}

\subsection{Contabilidade de hedge e Tributação}

O Pronunciamento Técnico do Comitê de Pronunciamentos Contábeis (CPC) 38 dispôs acerca das condições necessárias para a utilização da contabilidade de hedge a partir da caracterização de uma relação de hedge, com destaque para que a companhia detenha, desde o início do hedge, a designação e documentação formais da relação de hedge e do objetivo e estratégia da gestão de risco da entidade, incluindo a identificação do instrumento, a posição ou transação coberta e a natureza do risco a ser coberto, fatores de suma importância também para a abordagem tributária.

Nessa linha, Lopes, Galdi e Lima (2011) ressaltam que cabe à empresa interessada cumprir todos os requisitos necessários (incluindo a adequada documentação) para demonstrar que as operações realizadas com instrumentos financeiros derivativos são efetivamente de hedge e consequentemente merecem tratamento de hedge accounting, ao contrário do que diz a norma norte-americana ${ }^{5}$, que, segundo Graham e Rogers (2002), requer apenas que as companhias informem, ao publicar suas demonstrações financeiras, se especulam com derivativos ou não ${ }^{6}$.

Guerra e Galdi (2009) ressaltam que as firmas utilizam derivativos com o principal intuito de gerenciar riscos por meio da diminuição da volatilidade do resultado; contudo, existe maior preocupação com aspectos institucionais e legais (tributação e tratamento contábil) do que com econômicos, o que demonstra a importância da questão tributária.

O artigo 249 do Decreto n. 3.000, de 26 de março de 1999 (Regulamento do Imposto de Renda - RIR/99) dispõe que, na determinação do lucro real, serão adicionadas ao lucro líquido do período de apuração, entre outros, as perdas incorridas em operações iniciadas e encerradas no mesmo dia (day-trade), realizadas em mercado de renda fixa ou variável, e as perdas apuradas nas operações realizadas nos mercados de renda variável e de swap, que excederem os ganhos auferidos nas mesmas operações.

Por tal, o conceito de hedge ganhou relevância significativa na legislação tributária brasileira a partir de 1995 , na medida em que o artigo 77 , inciso $\mathrm{V}$ e $\S \S 1^{\circ}$ ao $3^{\circ}$ da Lei $n$. 8.981 , de 20 de janeiro, estabeleceu que as perdas com operações com derivativos somente poderiam ter seus montantes deduzidos com vistas à apuração do lucro real quando estes fossem referentes a operações de hedge (LOPES; GALDI; LIMA, 2011).

Assim, de acordo com a legislação tributária brasileira, as operações financeiras com o intuito de hedge estão sujeitas a tratamento tributário diferenciado, inclusive quando praticadas no exterior e em mercados futuros fora de bolsa (art. 396 do RIR/99), prevendo como pré-requisitos para sua caracterização, basicamente, que o objeto do contrato negociado: (i) esteja relacionado com as atividades operacionais da pessoa jurídica; e (ii) destine-se à proteção de direito ou obrigações da pessoa jurídica.

Lameira, Figueiredo e Ness Jr. (2005), em artigo que tratou da redução de volatilidade dos lucros e o efeito na apuração do imposto de renda das companhias abertas brasileiras,

\footnotetext{
5 Statement of Financial Accounting Standards - SFAS 133, publicado pelo Financial Accounting Statements Board - FASB.

${ }^{6}$ Como era de se esperar, na amostra utilizada no estudo de Graham e Rogers (2002), nenhuma empresa sujeita à exposição ao risco ex-ante declarou praticar qualquer atividade especulativa.
} 
buscaram verificar se aquelas que fizeram hedge para se protegerem do risco de aumento de taxa de câmbio e dos juros, nos anos de 2002 e 2003, conseguiram alguma vantagem tributária, diminuindo o valor do IRPJ a pagar em relação a caso não tivessem feito hedge, concluindo que de fato as empresas que eliminam a volatilidade de seus resultados a partir da prática de operações de hedge - que ora são negativos, ora positivos - agregam valor ao seu patrimônio, em decorrência da queda do valor do imposto sobre seus lucros.

A Figura 1 ilustra a diferença de tratamento dado pela legislação tributária brasileira às operações financeiras com e sem o intuito de hedge:

\section{Figura 1 - Sistemática de tributação das operações financeiras de renda variável pelo IRPJ (lucro real)}

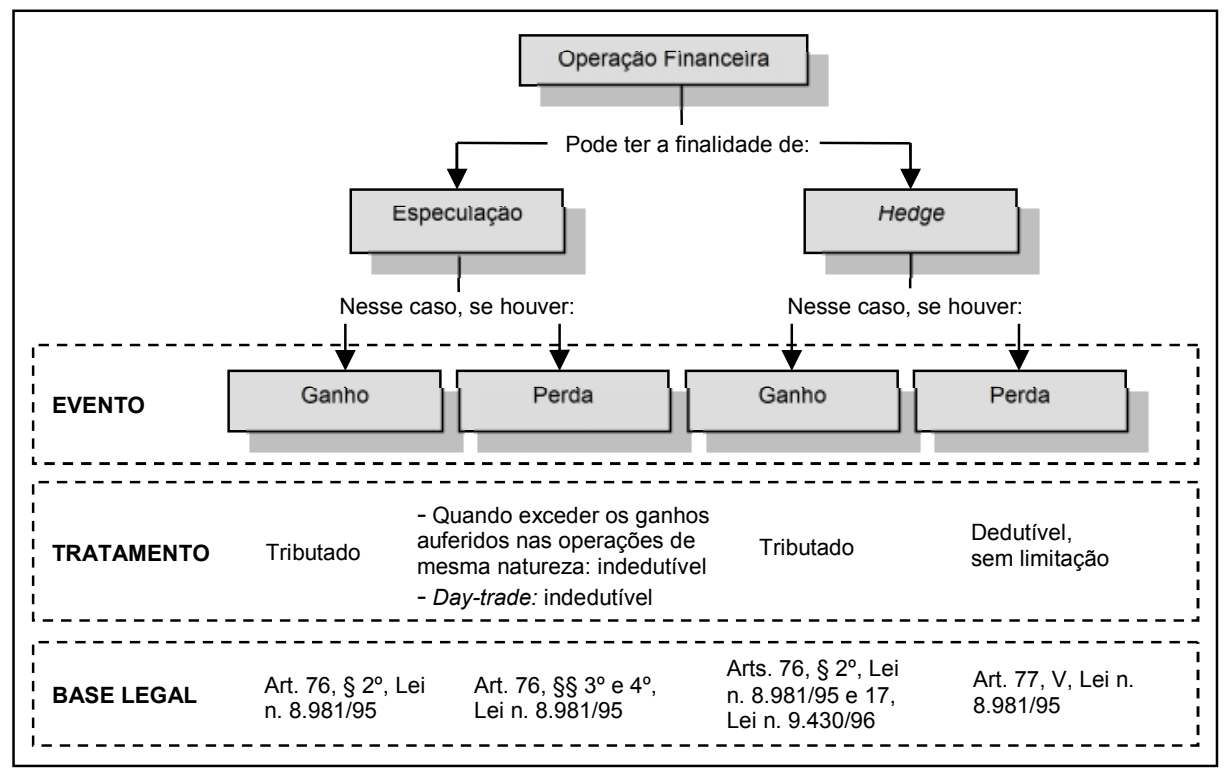

Fonte: Elaborada pelos autores, com base nas Leis n. 8.981/95 e n. 9.430/96.

A sistemática descrita na Figura 1, adotada pela legislação tributária brasileira, não é exclusiva: da mesma forma, tomando-se por base a legislação norte-americana, Lien e Metz (2002) e Milevsky e Prisman (1999) destacam a jurisprudência da Suprema Corte norteamericana nos casos emblemáticos de 1955 (Corn Products) e 1988 (Arkansas Best), tendo neste último proibida a compensação entre mesmos ganhos e perdas em operação financeira de hedge, por esta não se enquadrar em classes restritas de transação previstas na seção 1221 do regulamento do imposto de renda norte-americano ${ }^{7}$.

Contudo, Lopes, Galdi e Lima (2011) ressaltam que a legislação tributária brasileira não promoveu um aprofundamento da definição e nos critérios de eficácia das operações de hedge, ou ainda na definição dos tipos de hedge, como fez o CPC 38; dessa forma, concluem os autores pela importância das definições econômicas e contábeis para a adequada caracterização das operações de hedge, pois o legislador tributário não adentrou em maiores detalhes a respeito da conceituação e comprovação dessas operações, remetendo a análise no que se refere à comprovação do hedge à literatura técnica do assunto.

${ }^{7}$ IRC - Internal Revenue Code. 
Assim, a comprovação de hedge por parte do contribuinte é uma forma de reduzir a assimetria de informação em sua relação com o Fisco, pois, como este não possui informação completa a respeito das transações econômicas realizadas pela empresa, o contribuinte necessita de mecanismos para reduzir o risco de informação enganosa; essa relação pode ser observada do ponto de vista da Teoria Econômica, que procura explicar as relações contratuais entre duas partes.

\subsection{Comprovação de hedge e assimetria de informação}

Pentland e Carlile (1996) destacam a existência de informação imperfeita e incompleta na relação Fisco-contribuinte, devido ao fato de o auditor fiscal, em particular, ser ignorante quanto ao que o contribuinte tem realmente feito, caracterizando a motivação fundamental da auditoria: assimetria informacional.

Pohlmann e Iudícibus (2006) destacam que na relação entre Estado e contribuinte, o primeiro (principal), visando maximizar sua utilidade, opta por delegar ao contribuinte (agente) a tarefa de apurar e recolher o imposto, independentemente de qualquer notificação, reduzindo seus custos de administração tributária e ganhando agilidade na arrecadação. Assim, a preocupação maior do Estado passa a ser a de criar meios de compelir o contribuinte a obedecer rigorosamente às normas fiscais, enquanto este passa a buscar meios de minimizar a carga tributária, uma vez que o montante do tributo não recolhido ao Estado irá lhe propiciar uma renda adicional.

Pentland e Carlile (1996, p. 270) examinaram a prática de auditoria do IRS (Internal Revenue Service) norte-americano e por isso afirmam que o processo de monitoramento do Fisco estende-se por meio de um elaborado conjunto de interações com os contribuintes. No aspecto prático, é difícil para o Fisco capturar e apurar tudo o que é devido, pois empresas têm registros elaborados que são volumosos e complexos e a meta do agente da Receita é procurar além da aparência superficial apresentada nos formulários fiscais e suportada nos documentos - registros podem ser forjados e livros falsificados, de modo que o agente deve adotar uma postura cética e "auditar o contribuinte, não a declaração".

Milevsky e Prisman (1999, p. 149) ressaltam, nesse contexto, que as discussões travadas pelo IRS têm sido resolvidas favoravelmente aos contribuintes em primeira instância administrativa (lower tax courts) ${ }^{8}$, por exemplo, tratando os instrumentos financeiros com a finalidade de hedge como sendo "recebíveis relativos aos negócios da empresa".

Portanto, a adequada comprovação de hedge por parte do contribuinte deve ocorrer como instrumento de redução da assimetria informacional em relação ao Fisco, também por meio de legislação que promova delineamento claro a respeito de o que o Fisco entende como sendo uma operação financeira com o intuito exclusivo de hedge.

\footnotetext{
8 Da mesma forma, Pedwell (2000), em sua pesquisa para examinar a aplicabilidade dos princípios de contabilidade geralmente aceitos na determinação da renda para fins de tributação, destacou que sua observância pelas empresas autuadas não demonstrou a mesma eficácia quando analisadas as decisões das cortes de apelação (segunda instância) em relação às cortes fiscais (primeira instância), cujo julgamento se restringe à correta avaliação da renda para fins de incidência do imposto, denotando a importância da análise contábil e documental nesta fase da discussão administrativa contra o Fisco.
} 


\section{Metodologia da Pesquisa}

As seguintes metodologias identificadas com a pesquisa em matéria tributária foram aplicadas neste estudo (MARTINS, 2002): (i) empírico-arquival; (ii) estudo de caso; e, (iii) pesquisa de campo. No que se refere à linha de pesquisa utilizada, remete-se à classificação das três principais áreas ou campos de pesquisa de Shackelford e Shevlin (2001): (i) a coordenação de fatores tributários e não tributários; (ii) os efeitos dos tributos sobre o preço dos ativos; e, (iii) a tributação do comércio internacional e interestadual, de forma que, neste trabalho, utiliza-se a pesquisa empírica como 'coordenação de fatores tributários e não tributários'.

Assim, os fatores que podem promover discordância entre Fisco e contribuinte na comprovação de hedge são examinados neste trabalho em duas fases de estudo, conforme Figura 2. Na primeira fase, foi realizado um estudo de caso envolvendo uma autuação fiscal pela não comprovação, ao menos do ponto de vista do Fisco, de hedge. Na segunda fase do estudo, a partir das observações do estudo de caso, foi realizada uma análise documental de decisões administrativas com o objetivo de verificar se os fatores identificados no estudo de caso são observados também em outras situações, envolvendo outros contribuintes brasileiros.

\section{Figura 2 - Fases da pesquisa}

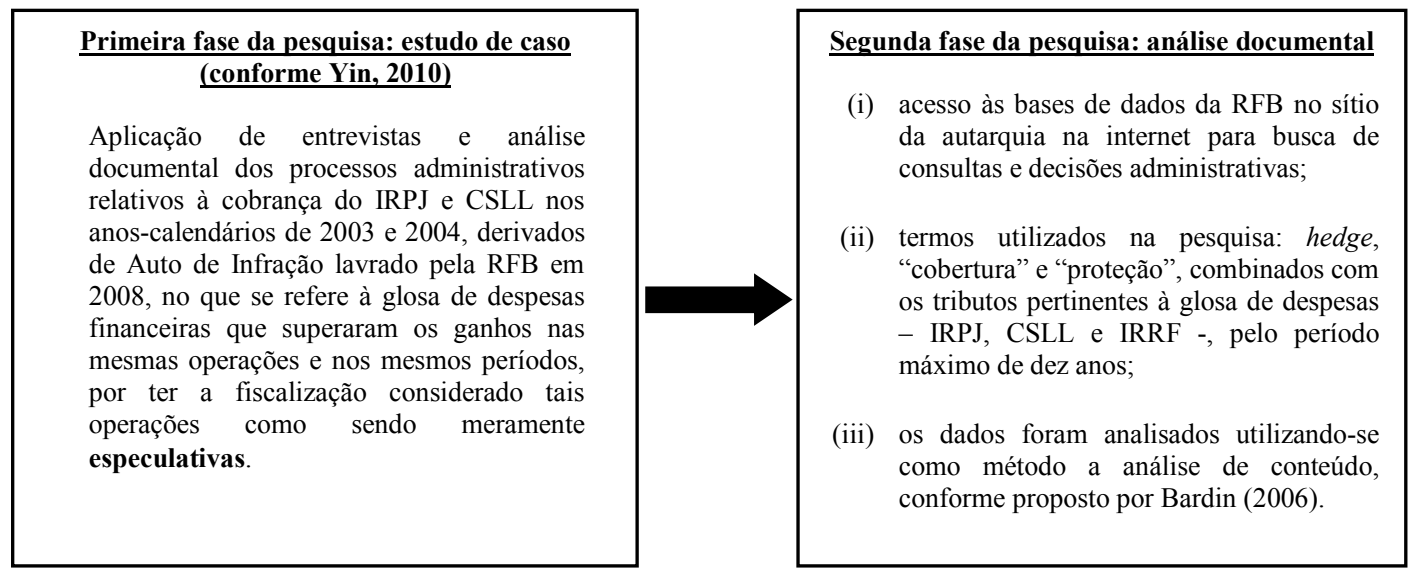

Fonte: Elaborada pelos autores.

O estudo de caso fora realizado a partir de autuação fiscal ocorrida em 2008 contra companhia brasileira (Companhia A) atuante no comércio internacional de commodities agrícolas (açúcar e etanol), na qual foram glosadas integralmente as perdas e despesas financeiras em operações com derivativos em bolsas de mercadorias e futuros internacionais (R\$ 11.008.506,39) e em contratos de swap com instituições financeiras brasileiras (R\$ 9.101.626,96) no cálculo do IRPJ e da CSLL dos anos-calendários de 2003 e 2004, gerando custo adicional à companhia, além das próprias perdas financeiras auferidas, no valor de $\mathrm{R} \$$ 16.438.314,10, considerando principal, juros de mora e multas de ofício.

Nesta pesquisa, foram acessados os demonstrativos fiscais e contábeis relativos aos anos-calendários de 2003 e 2004, bem como os controles internos das operações financeiras em bolsas de valores, mercadorias e futuros e no mercado de balcão organizado, incluindo os contratos de venda de açúcar e etanol para entrega futura, contratos de pré-pagamento à 
exportação e contratos de financiamento externo, além dos extratos das corretoras de valores responsáveis pelo registro das operações financeiras da companhia no Brasil e no exterior.

Ademais, no estudo de caso, foram realizadas entrevistas estruturadas com representantes da companhia, responsáveis pela política de risco, estratégia, controle, contabilização e definição da tributação dessas operações, conforme protocolo de estudo de caso elaborado com base nas normas internacionais do Committee of Sponsoring Organizations of the Treadway Commission (COSO) e nos termos preconizados por Yin (2010).

Nesta primeira fase da pesquisa, foram ainda objetos de análise os processos administrativos relativos à autuação fiscal do IRPJ e da CSLL, desde o início da fiscalização federal até a lavratura do Auto de Infração, analisando ainda fatores ex-ante relacionados à gestão do risco e controles gerenciais das operações financeiras praticadas pela companhia, o papel dos auditores independentes, bem como os argumentos de defesa, documentos, planilhas e gráficos elaborados e juntados por ocasião da apresentação de defesa administrativa (impugnação) e da diligência fiscal realizada por auditor fiscal especializado da RFB.

Com base nos elementos coletados no estudo de caso, foram definidos os termos e argumentos de pesquisa para a realização da segunda fase, que envolveu pesquisa documental e análise abrangente de soluções de consultas à RFB e decisões administrativas relativas ao tema "comprovação de hedge" - assim, a segunda fase da pesquisa consistiu no acesso às bases de dados da RFB no sítio da autarquia na internet ${ }^{9}$ para busca de soluções de consultas de contribuintes, de decisões de primeira instância das Delegacias Regionais de Julgamento (DRJ) de todo o país e dos acórdãos do Conselho de Recursos Administrativos Fiscais (CARF), utilizando três termos, conforme legislação tributária analisada e literatura acerca do tema: hedge, "cobertura" e "proteção", combinados com os tributos pertinentes à glosa de despesas (IRPJ, CSLL e Imposto de Renda Retido na Fonte - IRRF), referentes aos anoscalendários de 1999 a 2010.

Os dados selecionados na pesquisa foram analisados utilizando-se como método a análise de conteúdo, conforme proposto por Bardin (2006), sendo gerado como resultado uma tabela contendo trechos relevantes das decisões e a contagem dos fatores, para uma nova análise qualitativa e quantitativa dos dados e confrontação com a teoria pesquisada.

\section{Estudo de Caso}

A Companhia A, objeto do estudo de caso, é uma empresa comercial exportadora cujo objeto social principal é a originação de commodities agrícolas - açúcar e etanol - no mercado interno para posterior revenda nos mercados interno e externo, colocando à disposição de seus quotistas - unidades produtoras (usinas) de açúcar e álcool - sua estrutura administrativa e foco na gestão de contratos, logística e estruturação financeira com instituições do Brasil e do exterior.

Assim, conforme informações colhidas durante o estudo de caso, a Companhia A praticava com frequência operações financeiras em bolsas de mercadorias e futuros, dispondo

\footnotetext{
${ }^{9}$ Disponível no link: < http://www.receita.fazenda.gov.br/DefesaContribuinte/ementarios.htm>.
} 
de mesa de operações para negociar as commodities que comercializava, exclusivamente em bolsas no exterior, por intermédio de corretoras internacionais.

A companhia praticava com frequência ainda operações financeiras no mercado de balcão organizado, pela utilização de contratos de swap com bancos nacionais (troca de fluxo de dólar pela taxa de negociação de $\mathrm{CDI}^{10}$ ) ou operações no mercado de balcão (over the counter) com futuros e opções de contratos de açúcar e gasolina no exterior. De acordo com informações da companhia, as mencionadas operações financeiras tinham por finalidade específica a proteção dos riscos de variação de dólar (ativos e passivos) e de variação do açúcar (sujeita à cotação em Nova Iorque) e etanol na venda.

Por outro lado, a Companhia A apurava o IRPJ e a CSLL, nos anos-calendários de 2003 e 2004, pelo método do Lucro Real anual, de modo que as perdas em operações financeiras com derivativos praticadas eram deduzidas em sua integralidade. Não havia qualquer tipo de controle apartado das posições protegidas e das operações com derivativos com objetivo de hedge, pois eram todas consideradas como tal.

Nesse cenário, a companhia foi intimada em 28/11/2008 da lavratura de Auto de Infração pela RFB, em decorrência de suposta falta/insuficiência de recolhimento de IRPJ e CSLL nos períodos de apuração compreendidos entre janeiro de 2003 e dezembro de 2004, nos montantes descritos na Tabela 1 - principal, multa de ofício de $75 \%$ do valor do débito, e juros de mora calculados pela Taxa de Sistema Especial de Liquidação e Custódia (SELIC).

Tabela 1 - Composição do crédito tributário apurado - IRPJ e CSLL

\begin{tabular}{c|c|c|c}
\hline \multirow{2}{*}{ Descrição } & \multicolumn{3}{|c}{ Valor (R\$) } \\
\cline { 2 - 4 } & IRPJ & CSLL & Total \\
\hline Imposto & $5.027 .533,34$ & $1.846 .737,45$ & $6.874 .270,79$ \\
\hline Juros de mora (calculados até 31/10/2008) & $3.223 .427,07$ & $1.184 .913,17$ & $4.408 .340,24$ \\
\hline Multa proporcional & $3.770 .649,99$ & $1.385 .053,08$ & $5.155 .703,07$ \\
\hline Valor do crédito tributário apurado & $\mathbf{1 2 . 0 2 1 . 6 1 0 , 4 0}$ & $\mathbf{4 . 4 1 6 . 7 0 3 , 7 0}$ & $\mathbf{1 6 . 4 3 8 . 3 1 4 , 1 0}$ \\
\hline
\end{tabular}

Fonte: Processo administrativo objeto de análise no estudo de caso.

De acordo com o Auto de Infração, em procedimento de verificação do cumprimento das obrigações tributárias pelo sujeito passivo (companhia), fora identificada a ausência de adição ao lucro líquido do período (2003 e 2004) dos valores referentes a perdas indedutíveis em aplicações financeiras, excedentes aos ganhos auferidos nas mesmas operações, conforme Tabelas 2 e 3, extraídas e adaptadas do Termo de Constatação e Intimação Fiscal, anexo ao Auto de Infração.

Tabela 2 - Perdas em Aplicações Financeiras (renda variável) não adicionadas ao Lucro Real Ano-calendário de 2003 - Operações com swap

\begin{tabular}{c|c|c|c}
\hline A & B & C & D \\
\hline ANO & Perdas & Ganhos & $\begin{array}{c}\text { Valor tributável } \\
\text { (B-C) }\end{array}$ \\
\hline 2003 & $712.301,80$ & - & $712.301,80$ \\
\hline TOTAL & $\mathbf{9 . 1 0 1 . 6 2 6 , 8 6}$ & - & $\mathbf{9 . 1 0 1 . 6 2 6 , 8 6}$ \\
\hline
\end{tabular}

Fonte: Processo administrativo objeto de análise no estudo de caso.

${ }^{10}$ Certificado de Depósito Interbancário. 
Fatores que promovem discordâncias entre fisco e contribuinte a respeito da comprovação de hedge

Tabela 3 - Perdas x Ganhos/Prêmios em Operações de Bolsa exceto day-trade e swap - Anoscalendários de 2003 e 2004.

\begin{tabular}{c|c|c|c|c}
\hline $\mathbf{A}$ & $\mathbf{B}$ & $\mathbf{C}$ & $\mathbf{D}$ & $\mathbf{E}$ \\
\hline MÊS/ANO & $\begin{array}{c}\text { Despesa/perda e } \\
\text { pgto. de prêmio }\end{array}$ & Ganhos & $\begin{array}{c}\text { Prêmios } \\
\text { recebidos }\end{array}$ & $\begin{array}{c}\text { Valor tributável } \\
\text { (B-C-D) }\end{array}$ \\
\hline 2003 & $16.079 .164,18$ & $2.264 .382,78$ & $5.937 .549,35$ & $7.877 .232,05$ \\
\hline 2004 & $16.398 .848,22$ & $4.739 .884,39$ & $8.527 .689,49$ & $3.131 .274,34$ \\
\hline TOTAL & $\mathbf{3 2 . 4 7 8 . 0 1 2 , 4 0}$ & $\mathbf{7 . 0 0 4 . 2 6 7 , 1 7}$ & $\mathbf{1 4 . 4 6 5 . 2 3 8 , 8 4}$ & $\mathbf{1 1 . 0 0 8 . 5 0 6 , 3 9}$ \\
\hline
\end{tabular}

Fonte: Processo administrativo objeto de análise no estudo de caso.

Diante da autuação fiscal em questão, a companhia, por intermédio de seus procuradores, dentro do prazo legal de 30 dias, apresentou impugnação perante a DRJ da RFB local, no intuito de afastar a cobrança do IRPJ e da CSLL incidentes sobre as perdas e despesas financeiras deduzidas no cálculo do lucro real sem a limitação dos ganhos, tendo em vista a natureza de hedge das mencionadas operações financeiras.

Por ocasião da impugnação, a Companhia A requereu nova diligência fiscal aos documentos e demonstrativos da empresa, com vistas a provar suas alegações, sendo que os principais argumentos levantados foram:

(i) os saldos mensais em US\$ (passivo em aberto) dos financiamentos mantidos no período eram superiores aos montantes mensais por esta operados em contratos de swap no mesmo período;

(ii) as perdas totais em operações de swap no período, decorrentes da queda na cotação da moeda norte-americana ao longo do ano de 2003, foram integralmente suplantadas pelos ganhos (receitas) mensais contabilizados pela empresa com variações cambiais vinculadas aos contratos de financiamento em aberto;

(iii) se os saldos mensais de operações financeiras com futuros e opções são inferiores aos saldos mensais de ativos e passivos vinculados à atividade operacional da companhia e expostos ao risco de variação de preços, pode-se afirmar com segurança que se trata de operação de cobertura (hedge). Os mencionados saldos mensais se referem aos valores nocionais das opções em aberto e podem ser mensurados pelo somatório de todos os preços de exercício (strikes) multiplicado pelo volume de mercadoria (commodity) negociado em cada contrato;

(iv) se o resultado econômico gerado pela variação do preço das commodities negociadas pela empresa for positivo, ainda que após cotejado com o resultado financeiro negativo (perdas auferidas/prêmios pagos) gerado pelas operações financeiras com derivativos de mesma espécie, verifica-se que o intuito de proteger-se (hedge) foi atingido.

Diante dos argumentos acima, o pedido de diligência fiscal foi acatado pelos julgadores administrativos de primeira instância, oportunidade em que a Companhia A apresentou contratos de financiamento e razões contábeis auxiliares (contas de "empréstimos e financiamentos", no passivo circulante e não circulante) como evidências de que mantinha, durante o período fiscalizado, linhas de financiamento em dólares norte-americanos perante diversas instituições financeiras, passíveis de variação cambial em função da cotação da moeda norte-americana, tendo demonstrado que especificamente no ano-calendário de 2003, a cotação da moeda norte-americana no Brasil sofreu variações bruscas, conforme cotações oficiais divulgadas pelo Banco Central do Brasil (Bacen) - Gráfico 1.

Dessa forma, em decorrência da volatilidade cambial verificada, a Companhia A auferiu ganhos decorrentes de variação cambial, devidamente contabilizados (os razões 
auxiliares das contas contábeis de receita e despesa foram juntadas ao processo administrativo), haja vista que possuía contratos de financiamentos em dólar (Tabela 4).

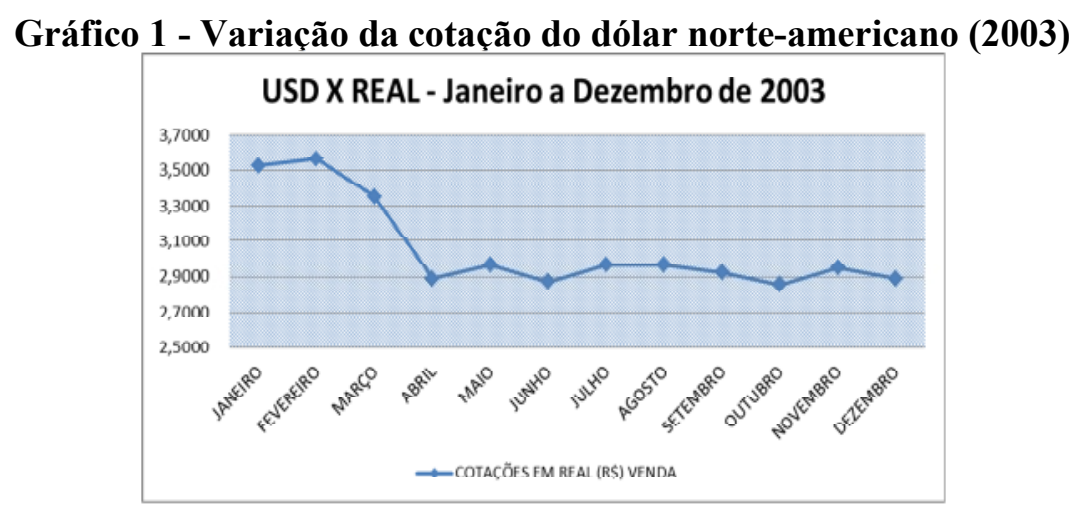

Fonte: Processo administrativo objeto de análise no estudo de caso.

Tabela 4 - Variações cambiais decorrentes dos Contratos de Financiamentos (passivo)

\begin{tabular}{c|c|c|c}
\hline $\begin{array}{c}\text { Mês de } \\
\text { apropriação }\end{array}$ & $\begin{array}{c}\text { Receita variação } \\
\text { cambial }\end{array}$ & $\begin{array}{c}\text { Despesa variação } \\
\text { cambial }\end{array}$ & $\begin{array}{c}\text { Ganho/Perda } \\
\text { líquido }\end{array}$ \\
\hline $\mathrm{Mar} / 2003$ & $2.414 .348,07$ & $109.148,16$ & $2.305 .199,91$ \\
\hline $\mathrm{Abr} / 2003$ & $26.471 .368,10$ & & $26.471 .368,10$ \\
\hline $\mathrm{Mai} / 2003$ & & $3.307 .132,37$ & $(3.307 .132,37)$ \\
\hline $\mathrm{Jun} / 2003$ & $3.984 .790,30$ & & $3.984 .790,30$ \\
\hline $\mathrm{Jul} / 2003$ & & $3.173 .591,49$ & $(3.173 .591,49)$ \\
\hline $\mathrm{Ago} / 2003$ & $3.105,71$ & $430.318,79$ & $(427.213,08)$ \\
\hline
\end{tabular}

Fonte: Processo administrativo objeto de análise no estudo de caso.

Assim, com fundamento na volatilidade da cotação da moeda norte-americana, a Companhia A apresentou os contratos de swap firmados com diversas instituições financeiras brasileiras, com os respectivos registros no sistema CETIP (serviço de registro eletrônico autorizado pelo Bacen) e conforme valores contabilizados nas contas de ativo (circulante e não circulante).

Ademais, a Companhia A afirmou que foram essas mesmas operações que geraram as "perdas com swap" objetos de glosa por parte da RFB, as quais foram comprovadamente contabilizadas como despesas do período de competência, conforme extratos de liquidação das operações apresentados, resumidas no Gráfico 2.

Gráfico 2 - Composição das perdas com operações de swap (2003)

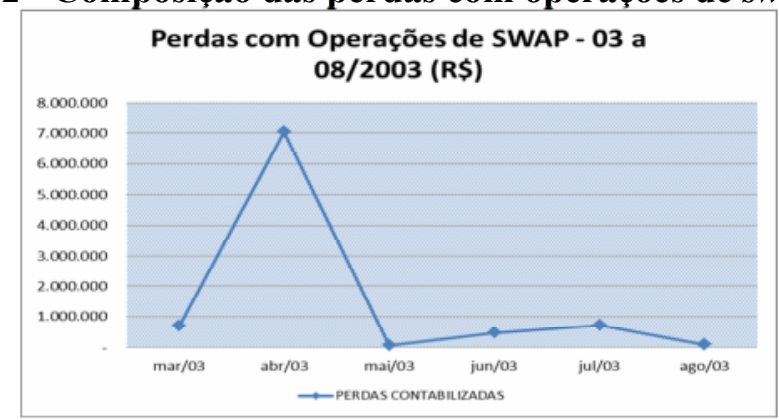

Fonte: Processo administrativo objeto de análise no estudo de caso. 
Como forma de comprovar o resultado econômico da operação de swap, a Companhia A demonstrou que as perdas (despesas) mensais decorrentes desses contratos foram inferiores aos ganhos (receitas) mensais contabilizados com variações cambiais, vinculadas aos contatos de financiamento em aberto com as instituições financeiras, conforme Tabela 5.

Tabela 5 - Variações cambiais decorrentes dos Contratos de Financiamentos (passivo) x perdas decorrentes de operações com swap

\begin{tabular}{c|c|c}
\hline Mês & Ganho/Perda líquido & $\begin{array}{c}\text { Perda decorrente } \\
\text { operações com swap }\end{array}$ \\
\hline $\mathrm{Mar} / 03$ & $2.035 .199,91$ & $(712.301,80)$ \\
\hline $\mathrm{Abr} / 03$ & $26.471 .368,10$ & $(7.045 .735,34)$ \\
\hline $\mathrm{Mai} / 03$ & $(3.307 .132,37)$ & $(63.038,55)$ \\
\hline $\mathrm{Jun} / 03$ & $3.984 .790,30$ & $(472.375,12)$ \\
\hline $\mathrm{Jul} / 03$ & $(3.173 .591,49)$ & $(724.231,45)$ \\
\hline $\mathrm{Ago} / 03$ & $(427.213,08)$ & $(83.914,70)$ \\
\hline
\end{tabular}

Fonte: Processo administrativo objeto de análise no estudo de caso.

A Companhia A demonstrou ainda que os saldos mensais em US\$ (passivo em aberto) dos financiamentos mantidos de abril a agosto de 2003 (meses em que as perdas excederam os ganhos) eram superiores aos valores nocionais mensais por esta operados em contratos de swap no mesmo período, conforme Gráfico 3.

Gráfico 3 - Comparativo de operações de swap e saldo de contratos financeiros (2003)

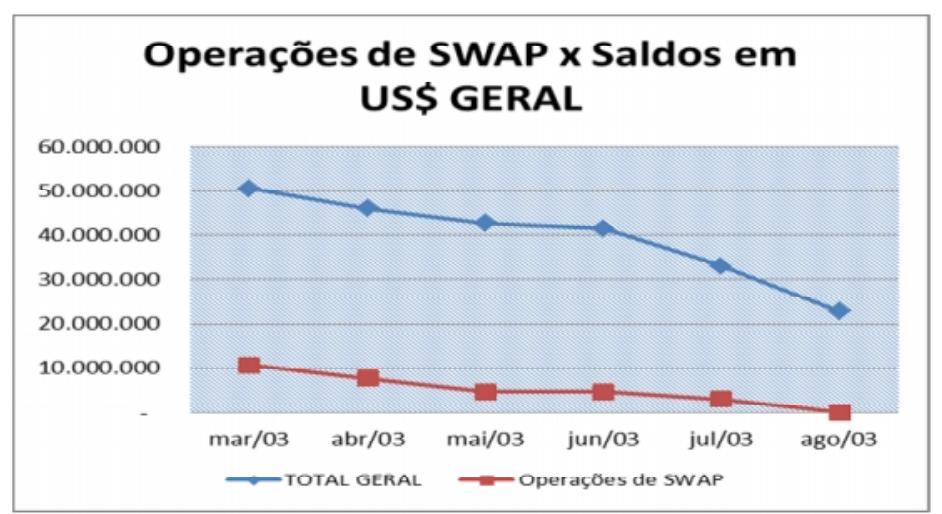

Fonte: Processo administrativo objeto de análise no estudo de caso.

Por outro lado, a Companhia A demonstrou ainda que as perdas totais em operações de swap no período de abril a agosto de 2003 (R\$ 9.101.626,96), decorrentes da queda na cotação da moeda norte-americana ao longo do ano de 2003, foram integralmente suplantadas pelos ganhos (receitas) mensais contabilizados pela empresa com variações cambiais vinculadas aos contratos de financiamento em aberto, os quais, líquidos das despesas contabilizadas da mesma natureza, montaram R\$25.853.421,37 no período, gerando resultado econômico tributável de $\mathrm{R}$ \$ 16.751.794,41 nas operações financeiras questionadas pelo físco federal.

No que se refere às operações com futuros e opções em bolsas de mercadorias e futuros no exterior, a Companhia $\mathrm{A}$ informou à fiscalização ter celebrado, nos anos-calendário 
de 2002, 2003 e 2004, inúmeros contratos com importadores de açúcar no exterior, os quais já haviam sido juntados ao processo administrativo, na apresentação da defesa, contendo os volumes mensais que eram devidos pela empresa desde a data da contratação e que deviam ser entregues de acordo com a cadência ${ }^{11}$ estipulada pelos compradores no ato da negociação.

Assim, cada contrato de exportação apresentado pela Companhia A continha todas as informações pertinentes à qualidade do açúcar ou etanol, quantidade a ser exportada, datas de embarque, multas por atraso de embarque ou prêmios por adiantamento, terminal portuário e preço referencial para os produtos entregues, fixado de acordo com o contrato padronizado $\mathrm{n}$. 11 da $\mathrm{ICE}^{12}$ (no caso do açúcar), gerando uma expectativa de receita para a empresa em decorrência desses contratos.

Dessa forma, a cada contrato celebrado, considerando-se o risco de variação de preços do açúcar (e do etanol) negociado, a Companhia A praticava operações com derivativos com o intuito de hedge - proteção contra variações na cotação dos preços desde a data do compromisso de venda até a data da efetiva entrega, quando eram calculados os preços finais de venda (receita de exportação), de acordo com a cotação do preço do produto naquela data (preço à vista - spot).

Logo, a Companhia A demonstrou, por meio do Gráfico 4, que no período de agosto de 2002 a dezembro de 2004, a cotação do preço do açúcar (VHP) teria sofrido altas expressivas no mercado mundial (ICE - Contrato n. 11).

Por tal, a Companhia A elaborou e apresentou à fiscalização demonstrativo contendo a data do fechamento de cada contrato, período de vencimento, período de exposição de contratos de venda, data da liquidação, preço (strikes), quantidade de contratos, volume por contrato e, finalmente, por volume negociado em US\$. Em seguida, a empresa apresentou à fiscalização cada contrato operado em bolsa de acordo com o período mensal de exposição para os anos-calendário 2003 e 2004.

\section{Gráfico 4 - Variação da cotação mensal do açúcar na bolsa de Nova York (2002/2003/2004)}

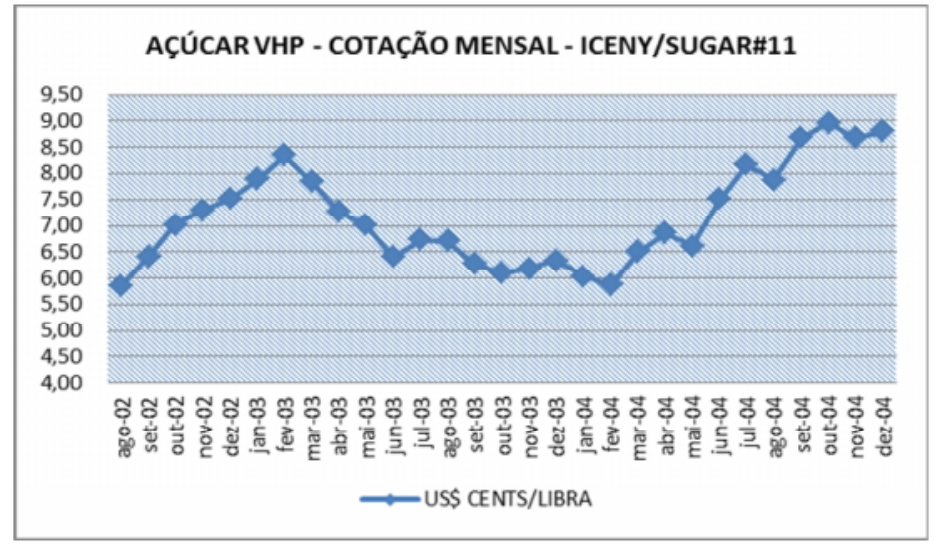

Fonte: Processo administrativo objeto de análise no estudo de caso.

\footnotetext{
${ }^{11}$ Cronograma de entrega de mercadoria adquirida em lotes ou grandes quantidades.

${ }^{12}$ IntercontinentalExchange - Bolsa de Valores, Mercadorias e Futuros de Nova York, antiga New York Board of Trade (NYBOT).
} 
A Companhia A, ademais, afirmou operar de diversas maneiras no mercado de derivativos, tendo realizado compras e vendas de opções relativas ao contrato de açúcar na ICE (denominado de SUGAR\#11), tanto de compra (calls) como de venda (puts), a depender das tendências do mercado de commodities agrícolas e da estratégia financeira definida pela empresa, ressaltando que a posição tomada na bolsa anulou perfeitamente a variação de preço observado no mercado real ${ }^{13}$, tendo sido aquém dos saldos de obrigações futuras relacionadas à entrega dos volumes contratados de açúcar, conforme os Gráficos 5 e 6.

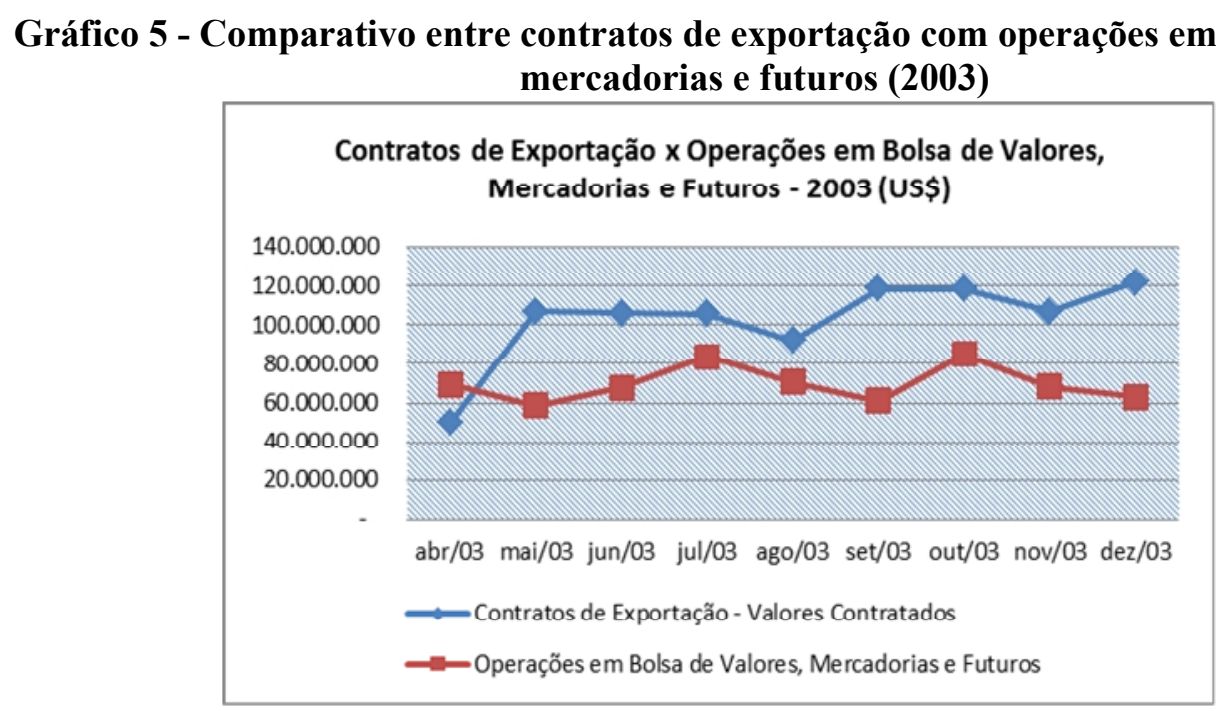

Fonte:Processo administrativo objeto de análise no estudo de caso.

\section{Gráfico 6 - Comparativo entre contratos de exportação com operações em bolsa de valores, mercadorias e futuros (2004)}

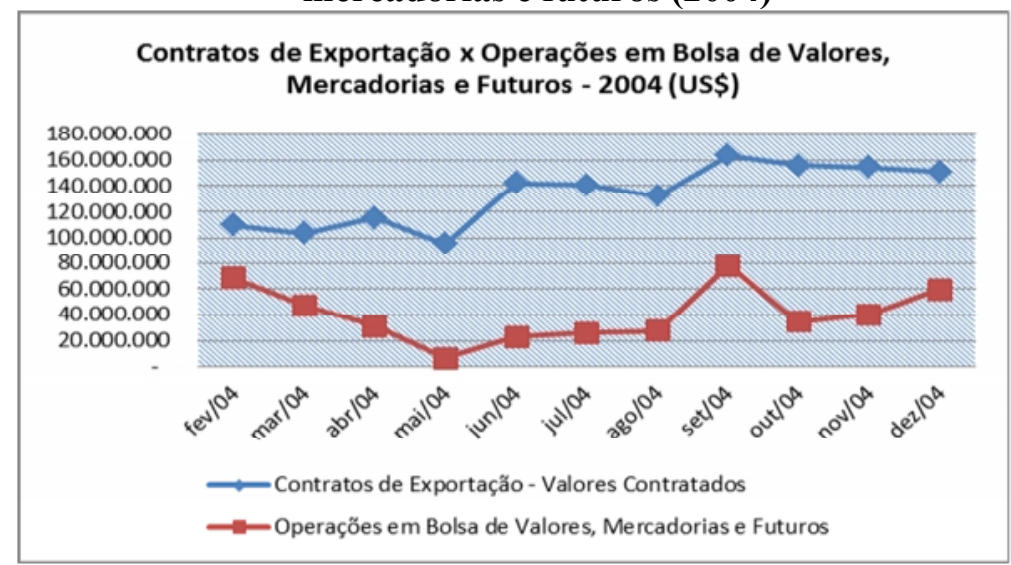

Fonte: Processo administrativo objeto de análise no estudo de caso.

Ao cotejar os ganhos percebidos pela Companhia A com a alta dos preços do açúcar com as perdas auferidas no período de abril de 2003 a dezembro de 2004, verifica-se que a

\footnotetext{
${ }^{13}$ Também denominado de "físico", ou seja, refere-se aos acréscimos ou decréscimos de receita bruta de venda de mercadorias auferidos por conta da variação de preços da própria commodity negociada. 
empresa apurou resultado econômico positivo de $\mathrm{R} \$ 17.070 .709,83$ nas operações em discussão, relativo ao ano-calendário de 2003. Já no ano-calendário de 2004, o resultado econômico apurado fora de $\mathrm{R} \$ 11.881 .722,37$.

Por fim, a Companhia A elaborou e apresentou à fiscalização demonstrativos comprovando a correlação dos contratos de exportação firmados com o volume de contratos negociados em bolsa de valores, mercadorias e futuros (valores em dólares), resumidos nas Tabelas 6 e 7.

Tabela 6 - Exposição: contratos de exportação x exposição em Bolsa - ano-calendário 2003

\begin{tabular}{c|c|c}
\hline Mês & $\begin{array}{c}\text { Contratos de } \\
\text { exportação em aberto }\end{array}$ & $\begin{array}{c}\text { Operações em bolsa (contrato } \\
\text { futuro SUGAR\#11) }\end{array}$ \\
\hline $\mathrm{Jan} / 03$ & $59.176,109$ & $48.321,843$ \\
\hline $\mathrm{Fev} / 03$ & $59.176,09$ & $73.405,767$ \\
\hline $\mathrm{Mar} / 03$ & $52.082,021$ & $63.215,079$ \\
\hline $\mathrm{Abr} / 03$ & $49.715,718$ & $69.471,959$ \\
\hline $\mathrm{Mai} / 03$ & $106.877,677$ & $58.443,330$ \\
\hline $\mathrm{Jun} / 03$ & $106.152,584$ & $67.875,181$ \\
\hline $\mathrm{Jul} / 03$ & $105.696,535$ & $83.674,886$ \\
\hline $\mathrm{Ago} / 03$ & $91.900,332$ & $70.455,930$ \\
\hline $\mathrm{Set} / 03$ & $118.188,798$ & $60.866,008$ \\
\hline $\mathrm{Out} / 03$ & $118.188,798$ & $85.001,526$ \\
\hline $\mathrm{Nov} / 03$ & $106.854,112$ & $68.203,397$ \\
\hline $\mathrm{Dez} / 03$ & $122.035,263$ & $63.157,573$ \\
\hline
\end{tabular}

Fonte: Processo administrativo objeto de análise no estudo de caso.

Assim, após a análise dos novos elementos trazidos pela Companhia A durante a diligência fiscal, foi emitido o Termo de Conclusão de Diligência Fiscal, que, por sua vez, representou a resposta do auditor fiscal responsável aos quesitos técnicos impostos pelos Julgadores da DRJ (primeira instância), para formação de sua convicção durante seu julgamento.

Tabela 7 - Exposição: contratos de exportação x exposição em Bolsa - ano-calendário 2004

\begin{tabular}{c|c|c}
\hline Mês & $\begin{array}{c}\text { Contratos de } \\
\text { exportação em aberto }\end{array}$ & $\begin{array}{c}\text { Operações em bolsa (contrato } \\
\text { futuro SUGAR\#11) }\end{array}$ \\
\hline $\mathrm{Fev} / 04$ & $109.535,916$ & $68.130,541$ \\
\hline $\mathrm{Mar} / 04$ & $103.899,252$ & $47.410,675$ \\
\hline $\mathrm{Abr} / 04$ & $115.227,458$ & $30.934,926$ \\
\hline $\mathrm{Mai} / 04$ & $95.486,116$ & $6.931,814$ \\
\hline $\mathrm{Jun} / 04$ & $141.991,908$ & $22.938,810$ \\
\hline $\mathrm{Jul} / 04$ & $140.656,691$ & $25.963,537$ \\
\hline $\mathrm{Ago} / 04$ & $132.283,397$ & $27.657,515$ \\
\hline $\mathrm{Set} / 04$ & $163.327,196$ & $77.943,555$ \\
\hline $\mathrm{Out} / 04$ & $156.018,343$ & $34.463,501$ \\
\hline $\mathrm{Nov} / 04$ & $154.649,280$ & $40.196,527$ \\
\hline $\mathrm{Dez} / 04$ & $150.977,433$ & $59.653,097$ \\
\hline
\end{tabular}

Fonte: Processo administrativo objeto de análise no estudo de caso.

No que se referiu às operações com swap, a fiscalização constatou que o contribuinte de fato mantinha linhas de financiamento atreladas à variação do dólar - em sua maioria, operações de pré-pagamento à exportação -, afirmando que, como houve a desvalorização do

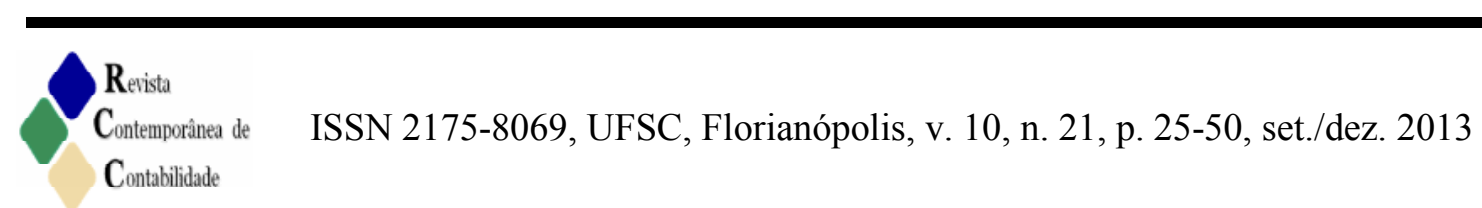


dólar norte-americano no período, tais contratos sofreram variação cambial ativa, configurando-se receita contabilizada e oferecida à tributação pelo IRPJ. Por outro lado, a fiscalização reconheceu que, para se proteger de eventuais valorizações cambiais, a Companhia A realizava aplicações por meio de operações de swap, tendo constatado que as perdas (despesas) mensais decorrentes dos contratos de swap foram bem inferiores aos ganhos (receitas) mensais contabilizados com variações cambiais vinculadas aos contatos de financiamento em aberto.

No que se referiu às operações com futuros e opções, a fiscalização também concluiu que os valores efetivos de receita de exportação auferidos pela Companhia A em decorrência da entrega do açúcar e etanol, sujeitos a variações em função da cotação em bolsas de mercadorias e futuros no exterior, foram maiores do que em relação à expectativa inicial, no ato da contratação, concluindo que 'é justamente esse tipo de variação que a contribuinte, operando os contratos futuros, deseja evitar'.

Dessa forma, a fiscalização concluiu que a Companhia A de fato realizou operações de hedge para se proteger contra variações bruscas de cotação de preços do açúcar e etanol, evitando, assim, perdas expressivas nas receitas de exportação por meio da contratação de operações com derivativos, podendo, portanto, considerar as perdas decorrentes como dedutíveis no cálculo do IRPJ, conforme determina a legislação tributária vigente.

$\mathrm{O}$ estudo de caso realizado demonstra a existência de divergências de interpretação e análise em função de assimetria de informação entre contribuinte e Fisco federal, relativa à comprovação da natureza de hedge das operações financeiras praticadas, na medida em que, diante da documentação colhida e apresentada pela Companhia A, bem como pelas entrevistas realizadas com os responsáveis pela empresa, verificou-se a existência de risco ex-ante de variação de preços de commodities e de cotação de moedas a ser protegido.

Nesse contexto, o estudo de caso aponta para que, mesmo na ausência de normas tributárias claras relativas ao hedge accounting para fins de comprovação da natureza de hedge de suas operações financeiras, a Companhia A conseguiu demonstrar com sucesso ao Fisco federal que estas visavam, nos anos-calendários de 2003 e 2004, proteger ativos e passivos devidamente registrados em seu balanço patrimonial e intrinsecamente relacionados a sua atividade operacional.

Além da questão documental, outro fator que pode ser observado no caso é a questão da atividade operacional realizada: a empresa fez hedge de operações com dólar, necessárias para se proteger de oscilações cambiais, inerentes à operação com exportações. Do mesmo modo, a empresa fez hedge de preço dos produtos comercializados, de modo a proteger-se de oscilações nos valores de mercado de seus produtos, que são commodities. Esse fator contribuiu para que fosse comprovada a existência de hedge, uma vez que a operação com derivativos que não estejam ligados à atividade operacional da empresa, nos termos da legislação tributária brasileira, não são de fato dedutíveis na apuração do lucro real.

Outro fator que também pode ser apontado a partir da observação do caso é a questão das estratégias de hedge adotadas. Swaps, futuros e opções foram os derivativos usados para a proteção de posições em dólar e posições de mercadorias sujeitas a oscilações de preço, derivativos compatíveis com a estratégia de proteção, já que os seus valores nocionais oscilam em sentido contrário à oscilação dos valores das posições protegidas. Se os instrumentos utilizados não fossem compatíveis com as posições protegidas, a comprovação de hedge para fins de dedução fiscal das perdas seria de difícil realização. 
Dessa forma, com base na análise acima, o estudo do caso oferece evidência de três possíveis fatores que podem contribuir para a ocorrência de divergências entre Fisco e contribuinte na comprovação do hedge: (i) comprovação documental; (ii) relação com a atividade operacional; e (iii) estratégias de hedge adotadas.

\section{Decisões administrativas sobre o tema}

Com base nos elementos colhidos no estudo de caso, conforme método descrito na Seção 3, foi realizada a segunda fase da pesquisa com o intuito de verificação em outras decisões da existência ou não dos mesmos fatores identificados nas análises relativas à Companhia A, cujos resultados gerais encontrados são demonstrados na Tabela 8.

Tabela 8 - Resultados encontrados na pesquisa na base de dados da RFB

\begin{tabular}{|c|c|c|c|c|c|c|}
\hline \multicolumn{5}{|c|}{ ARGUMENTOS DE PESQUISA } & \multicolumn{2}{|c|}{ RESULTADOS } \\
\hline Órgão & Tipo & Termo & Período & Tributo & Totais & Relacionados \\
\hline \multirow{9}{*}{ RFB } & \multirow{9}{*}{$\begin{array}{l}\text { Solução de } \\
\text { Consulta }\end{array}$} & \multirow{3}{*}{ Hedge } & \multirow{9}{*}{$\mathrm{n} / \mathrm{a}$} & IRPJ & 5 & 5 \\
\hline & & & & CSLL & 5 & 5 \\
\hline & & & & IRRF & 2 & 2 \\
\hline & & \multirow{3}{*}{ Cobertura } & & IRPJ & 5 & 0 \\
\hline & & & & CSLL & 0 & 0 \\
\hline & & & & IRRF & 16 & 1 \\
\hline & & \multirow{3}{*}{ Proteção } & & IRPJ & 3 & 0 \\
\hline & & & & CSLL & 0 & 0 \\
\hline & & & & IRRF & 1 & 0 \\
\hline \multirow{9}{*}{$\begin{array}{c}\text { Delegacia de } \\
\text { Julgamento da RFB }\end{array}$} & \multirow{9}{*}{$\begin{array}{c}\text { Decisão de } \\
\text { primeira instância }\end{array}$} & \multirow{3}{*}{ Hedge } & \multirow{9}{*}{$\mathrm{n} / \mathrm{a}$} & IRPJ & 24 & 23 \\
\hline & & & & CSLL & 2 & 2 \\
\hline & & & & IRRF & 9 & 9 \\
\hline & & \multirow{3}{*}{ Cobertura } & & IRPJ & 35 & 5 \\
\hline & & & & CSLL & 2 & 1 \\
\hline & & & & IRRF & 13 & 1 \\
\hline & & \multirow{3}{*}{ Proteção } & & IRPJ & 18 & 9 \\
\hline & & & & CSLL & 5 & 1 \\
\hline & & & & IRRF & 4 & 2 \\
\hline \multirow{3}{*}{ CARF } & \multirow{3}{*}{ Acórdão } & Hedge & \multirow{3}{*}{$05 / 2001$ a $05 / 2010$} & \multirow{3}{*}{$\mathrm{n} / \mathrm{a}$} & 13 & 10 \\
\hline & & Cobertura & & & 74 & 4 \\
\hline & & Proteção & & & 176 & 1 \\
\hline
\end{tabular}

Fonte: Dados da pesquisa.

Da análise da Tabela 8 é possível depreender que a utilização do termo hedge na pesquisa indica a correlação direta ao tema "comprovação de hedge", em todas as instâncias, da mesma forma em que quando utilizados os termos "cobertura" e "proteção", a maioria dos resultados retornados não tem correlação com o tema estudado.

Nota-se que no âmbito da RFB, poucas (7) são as Soluções de Consulta de contribuintes que tratam diretamente da questão da comprovação da natureza de hedge para fins de aproveitamento do benefício da dedutibilidade. Esse resultado pode ser explicado pelo fato de que a legislação aplicável às despesas financeiras e perdas auferidas nas operações de hedge é incontroversa, restando dúvidas tão somente na análise dos documentos que

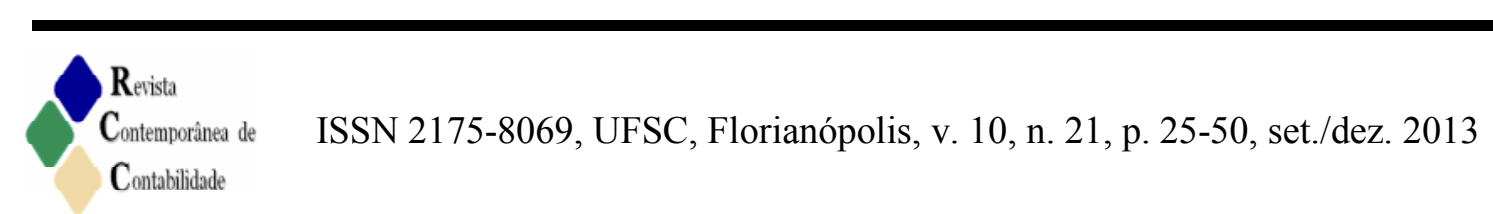


comprovam a efetividade das operações financeiras, análise esta que somente pode ocorrer mediante fiscalização da RFB.

No âmbito das DRJ da RFB espalhadas pelo país, diversos são os resultados retornados na pesquisa relativa ao tema "comprovação de hedge" e selecionados após a análise de conteúdo, fato esperado na medida em que nesta instância de julgamento é que são analisados os documentos juntados pelos contribuintes por ocasião da Impugnação aos Autos de Infração da RFB, conforme discutido por Pedwell (2000).

Nesse contexto, elaborou-se a Tabela 9 com base nos resultados retornados na pesquisa de julgados em primeira instância administrativa, contendo dados relativos ao número do acórdão, data, se favorável ou não ao contribuinte no que se refere à comprovação da natureza de hedge das operações financeiras e os argumentos utilizados pelos julgadores para fundamentar sua decisão.

Para elaboração da Tabela 9, com base nos elementos identificados no estudo de caso realizado, foram analisados três fatores nas decisões administrativas, a seguir descritos:

(i) atividade da empresa: questões relacionadas à correlação das operações financeiras praticadas com as atividades da companhia, seu objeto social e a existência ou não de outras operações consideradas especulativas;

(ii) comprovação documental: argumentos relacionados à necessidade de comprovação documental das operações financeiras praticadas, a comprovação da existência de ativos ou passivos a ser protegidos, a contabilização adequada de acordo com o regime de competência e a existência de registro no Bacen, sobretudo no que se refere às operações de swap;

(iii) estratégia de hedge: argumentos relativos à escolha do mecanismo e dos instrumentos financeiros específicos adotados pela companhia com a finalidade de hedge.

Já no âmbito do CARF - órgão colegiado responsável pelo julgamento de recursos dos contribuintes contra decisões desfavoráveis perante as DRJ, bem como de recursos de ofício da Fazenda Nacional em casos de derrota em primeira instância administrativa -, poucos são os acórdãos hábeis a delimitar um posicionamento claro, o que implica afirmar que ainda não há jurisprudência pacificada sobre o tema "comprovação de hedge".

Verifica-se que, depois de realizadas as buscas iniciais nas diferentes instâncias da RFB (consultas, decisões das DRJ e acórdãos do CARF), a análise mais profunda dos fatores que afetam o sucesso ou não da comprovação da natureza de hedge das operações financeiras praticadas pelas empresas somente foi possível no âmbito da primeira instância administrativa, confirmando a já citada hipótese de Pedwell (2000).

Nesse cenário, do total de 22 decisões de DRJ da RFB localizadas em todo o País, sete tiveram como argumento decisivo a discussão acerca da estratégia de hedge adotada pelo contribuinte autuado e oito tiveram como análise determinante pelos julgadores a correlação e/ou correta vinculação das operações financeiras praticadas pelo contribuinte autuado com sua atividade operacional, bem como com seu objeto social, conforme requer a legislação tributária que rege a matéria (art. 77, Lei n. 8.981/95).

Entretanto, chama a atenção o fato de que $68 \%$ das decisões de primeira instância analisadas (15) tenham deixado as questões acima de lado e tratado principalmente da questão documental relativa ao hedge. Esse resultado sugere a importância do tema comprovação de hedge para o sucesso das companhias brasileiras na defesa de autuações fiscais relativas à dedutibilidade de suas perdas financeiras na apuração do lucro real (IRPJ). 
Ademais, das 22 decisões selecionadas, apenas quatro foram favoráveis à existência de hedge e, portanto, aos contribuintes, o que implica afirmar que $82 \%$ dos textos analisados demonstraram que, na ausência de formulários ou controles internos obrigatórios, a posição do Fisco federal é de sustentar a glosa das despesas com operações financeiras, como se, de forma geral, o contribuinte não tivesse sido capaz de afastar de forma contundente e suficiente o caráter especulativo de suas operações financeiras com derivativos, em razão dos fatores descritos no Quadro 1.

\section{Quadro 1 - Fatores relevantes identificados na Análise Documental de decisões da RFB em} primeira instância administrativa

\begin{tabular}{|c|l|}
\hline Fator & \multicolumn{1}{c|}{ Descrição } \\
\hline Gerencial & $\begin{array}{l}\text { Comprovação de que as operações financeiras praticadas pelo contribuinte eram necessárias, usuais } \\
\text { e normais à atividade da companhia, inclusive quanto aos seus valores e volumes; comprovação de } \\
\text { que as operações com opções flexíveis de dólar correspondem à cobertura (hedge) destinada à } \\
\text { proteção contra oscilações da taxa de câmbio; comprovação de que as operações financeiras eram } \\
\text { pertinentes à proteção dos direitos e obrigações do contribuinte; apresentação das operações de } \\
\text { forma clara e inequívoca; e compatibilidade das operações financeiras praticadas pelo contribuinte } \\
\text { com a proteção cambial necessária. }\end{array}$ \\
\hline Contratual & $\begin{array}{l}\text { Comprovação da existência de ativos e passivos a serem protegidos, já registrados; suporte } \\
\text { documental adequado, idôneo, hábil a comprovar a normalidade e necessidade das operações } \\
\text { financeiras praticadas pelo contribuinte; e apresentação dos extratos de corretoras e demais } \\
\text { documentos que deram origens às aplicações. }\end{array}$ \\
\hline Contábil & $\begin{array}{l}\text { Existência de registro contábil como condição para que a operação financeira faça jus ao benefício } \\
\text { fiscal (dedutibilidade das perdas); contabilização adequada, em contas específicas cujas funções são } \\
\text { as de que se nelas registrem operações com propósito de hedge; e necessidade de contabilização } \\
\text { dos resultados (perdas e prêmios pagos) de acordo com o regime de competência, sob pena de } \\
\text { indedutibilidade. }\end{array}$ \\
\hline
\end{tabular}

Fonte: Dados da pesquisa.

Dessa forma, a pesquisa documental realizada, cujos resultados foram potencializados com a realização de análise de conteúdo embasada no que discutem a teoria e a legislação tributária brasileira, mostra-nos que o problema de pesquisa é real, é relevante e está presente no dia a dia das companhias brasileiras, na medida em que $82 \%$ das empresas autuadas pelo Fisco federal no período estudado não tiveram sucesso no afastamento das glosas de suas despesas financeiras de hedge na primeira instância administrativa, sem qualquer averiguação, por óbvio, se estas de fato realizavam ou não as operações financeiras com derivativos com este intuito.

Desse modo, pode-se concluir que os resultados obtidos nesta análise documental reforçam a identificação dos fatores apontados na análise do estudo de caso, uma vez que a presença ou ausência de um desses elementos mostrou-se preponderantemente determinante para o sucesso ou insucesso da comprovação de hedge nas operações examinadas, relativas a contribuintes em todo o Brasil e de variados setores da economia. 
Tabela 9 - Resultados da pesquisa de julgados em primeira instância administrativa

\begin{tabular}{|c|c|c|c|c|c|c|c|}
\hline Ordem & Acórdão & Data & Argumento & $\begin{array}{l}\text { Fator 1: } \\
\text { atividade } \\
\text { da } \\
\text { empresa }\end{array}$ & $\begin{array}{l}\text { Fator 2: } \\
\text { comprovação } \\
\text { documental }\end{array}$ & $\begin{array}{l}\text { Fator 3: } \\
\text { estratégia } \\
\text { de hedge }\end{array}$ & $\begin{array}{l}\text { Favorável } \\
\text { à } \\
\text { existência } \\
\text { de hedge? }\end{array}$ \\
\hline 1 & $\begin{array}{c}\mathrm{N}^{\circ} 16- \\
481\end{array}$ & 24/02/1999 & $\begin{array}{l}\text { Não logrando o contribuinte comprovar a existência de ativos a serem protegidos, correta é a glosa dos } \\
\text { prejuízos com hedge. }\end{array}$ & - $10-0$ & Ausente & - & Não \\
\hline 3 & $\begin{array}{l}\mathrm{N}^{\circ} 16- \\
213\end{array}$ & $31 / 12 / 2001$ & $\begin{array}{c}\text { As operações com SWAP e EXPORT NOTES, se não estiverem relacionadas com as atividades da } \\
\text { empresa ou não se destinarem à proteção de direitos e obrigações da mesma, é aplicável a glosa das } \\
\text { perdas que excederem aos ganhos da mesma natureza. }\end{array}$ & Ausente & Ausente & - & Não \\
\hline 4 & $\begin{array}{l}\mathrm{N}^{\mathrm{o}} 16- \\
1110\end{array}$ & $04 / 07 / 2002$ & $\begin{array}{l}\text { Perdas com operações de hedge suportadas por documentos inidôneos e perdas não caracterizadas como } \\
\text { despesas necessárias à atividade da empresa, possibilita o lançamento do IRPJ com retificações dos } \\
\text { prejuízos fiscais. }\end{array}$ & Ausente & Ausente & - & Não \\
\hline 5 & $\begin{array}{c}N^{\circ} 12- \\
1484\end{array}$ & $23 / 07 / 2002$ & $\begin{array}{l}\text { No caso específico de instituições financeiras, os ganhos e perdas com operações de hedge constituem, } \\
\text { respectivamente, acréscimo e dedução à base de cálculo do IRPJ por estimativa. }\end{array}$ & Presente & - & - & Sim \\
\hline 6 & $\begin{array}{c}\mathrm{N}^{\circ} 16- \\
1532\end{array}$ & $17 / 09 / 2002$ & $\begin{array}{l}\text { O gozo do benefício da alíquota zero do imposto de renda incidente nas remessas para beneficiários residentes } \\
\text { ou domiciliados no exterior, nas operações internacionais de cobertura de variações de paridade entre moedas } \\
\text { (hedge), impõe a comprovação de que tais operações sejam necessárias, usuais e normais, inclusive } \\
\text { quanto ao seu valor, para a realização da cobertura de riscos delas decorrentes, obedecida a regulamentação } \\
\text { pertinente. }\end{array}$ & - & Ausente & - & Não \\
\hline 7 & $\begin{array}{l}\mathrm{N}^{\circ} 16- \\
1597\end{array}$ & $01 / 10 / 2002$ & $\begin{array}{l}\text { Quando a operação de swap não se revelar pertinente às atividades da empresa ou à proteção de seus } \\
\text { direitos e obrigações, fica descaracterizado o propósito de cobertura de risco (hedge) da operação. Nesse } \\
\text { caso, para fins de dedutibilidade na determinação do lucro real, impõe-se o reconhecimento das perdas } \\
\text { apuradas em operações de swap somente até o limite dos ganhos auferidos nas operações de mesma natureza. }\end{array}$ & Ausente & - & - & Não \\
\hline 8 & $\begin{array}{l}\mathrm{N}^{\circ} 16- \\
2798\end{array}$ & $20 / 02 / 2003$ & $\begin{array}{l}\text { Mantido o lançamento haja vista a falta de apresentação de documentação hábil que comprove a } \\
\text { normalidade e necessidade dessas operações; existência de extratos que comprovam que a empresa fazia } \\
\text { operações day-trade, cujas perdas não podem ser consideradas para efeito de apuração do lucro real; não } \\
\text { comprovação de que tais operações eram de hedge; e pelo fato de que a empresa nunca teve como objeto } \\
\text { social a prática de operações em bolsa de valores ou de mercadorias. }\end{array}$ & Ausente & Ausente & - & Não \\
\hline 9 & $\begin{array}{c}\mathrm{N}^{\circ} 12- \\
3794\end{array}$ & $29 / 04 / 2003$ & $\begin{array}{c}\text { Se existirem operações contabilizadas em contas cujas funções são as de que se nelas registrem operações } \\
\text { com propósito de hedge, deve-se supor que elas de fato tenham esse objetivo e não de especulação como } \\
\text { alega o contribuinte, mas não o comprova devidamente. }\end{array}$ & - & Presente & - & Sim \\
\hline 10 & $\begin{array}{l}\mathrm{N}^{\circ} 06- \\
3605\end{array}$ & 08/05/2003 & $\begin{array}{c}\text { O repasse de obrigações contraídas em moeda estrangeira, para recebimento em moeda nacional, implica } \\
\text { riscos suscetíveis de serem neutralizados ou minimizados por meio de hedge, regulamentado pela Circular n. } \\
\text { 2.348, de 1993, do Banco Central do Brasil. Nessa categoria, entretanto, não se classificam operações de Non } \\
\text { Delivery Currency Forward pelas quais o repassador, em vez de contratar a compra futura de dólares, } \\
\text { contrata a venda futura dessa moeda, posto que o efeito dessas operações é inverso, ou seja, de ampliar, em } \\
\text { vez de minimizar ou neutralizar o risco cambial. }\end{array}$ & - & - & Ausente & Não \\
\hline 11 & $\begin{array}{l}\mathrm{N}^{\circ} 12- \\
4460\end{array}$ & $31 / 10 / 2003$ & $\begin{array}{l}\text { É admissível, para fins de apuração do Imposto de Renda Pessoa Jurídica, a dedução das perdas decorrentes de } \\
\text { operações de cobertura (hedge) realizadas em mercados de liquidação futura, diretamente pela empresa } \\
\text { brasileira, em bolsas no exterior (...). Podem ser objeto de proteção (hedge) contra o risco de variações de } \\
\text { taxas de juros, de paridades entre moedas e de preços de mercadorias, no mercado internacional, os } \\
\text { pagamentos e recebimentos em moedas estrangeiras programados ou previstos para ocorrerem em }\end{array}$ & - & - & Presente & Sim \\
\hline
\end{tabular}

45 ISSN 2175-8069, UFSC, Florianópolis, v. 10, n. 21, p. 25-50, set./dez. 2013

Rerista

Contemporinea de

Contabilidade 


\begin{tabular}{|c|c|c|c|c|c|c|c|}
\hline 12 & $\begin{array}{l}\mathrm{N}^{\circ} 16- \\
4597\end{array}$ & $16 / 12 / 2003$ & $\begin{array}{l}\text { Por não lograr comprovar que as operações com opcões flexíveis de dólar correspondem à cobertura } \\
\text { (hedge) destinada à proteção contra oscilações da taxa de câmbio, tais operações não estão excepcionadas } \\
\text { da limitação para a dedução das perdas havidas. }\end{array}$ & - & Ausente & Ausente & Não \\
\hline 13 & $\begin{array}{l}N^{\circ} 16- \\
4719\end{array}$ & $22 / 01 / 2004$ & $\begin{array}{l}\text { As perdas apuradas em operações de } s w a p \text { somente são dedutíveis até o limite dos ganhos nas operações de } \\
\text { mesma natureza se estiverem devidamente registradas. Somente não se deve observar o limite dos ganhos se o } \\
\text { swap teve finalidade de hedge ou a operação é da atividade operacional da empresa. Correta a glosa das } \\
\text { perdas quando não ficou demonstrado que as operações foram registradas e tampouco que tiveram } \\
\text { finalidade de hedge. }\end{array}$ & - & Ausente & - & Não \\
\hline 14 & $\begin{array}{l}\mathrm{N}^{\circ} 15- \\
5086 \\
\end{array}$ & $08 / 04 / 2004$ & $\begin{array}{c}\text { Inexistente o ativo a ser protegido objeto das operações de swap com cobertura (hedge) destinadas à } \\
\text { proteção de ativo em ouro contra oscilações da taxa de câmbio, deve ser mantida a glosa. }\end{array}$ & - & Ausente & - & Não \\
\hline 15 & $\begin{array}{c}N^{\circ} 15- \\
5782 \\
\end{array}$ & 08/09/2004 & $\begin{array}{l}\text { Mantida a glosa de despesa contabilizada a título de variações monetárias passivas, referente à operação de } \\
\text { hedge, com o objetivo de desbloquear valores em cruzados, por ser desnecessária à atividade da empresa. }\end{array}$ & Ausente & - & - & Não \\
\hline 16 & $\begin{array}{l}\mathrm{N}^{\circ} 16- \\
7045\end{array}$ & $09 / 05 / 2005$ & $\begin{array}{l}\text { Por não lograr comprovar que as operações com opções flexíveis de dólar correspondem à cobertura } \\
\text { (hedge) destinada à proteção contra oscilações da taxa de câmbio, tais operações não estão excepcionadas } \\
\text { da limitação para a dedução das perdas havidas. }\end{array}$ & - & Ausente & Ausente & Não \\
\hline 17 & $\begin{array}{l}N^{\circ} 12- \\
14174\end{array}$ & $18 / 05 / 2007$ & $\begin{array}{l}\text { Quando a operação de swap não se revelar pertinente à proteção dos direitos e obrigações do } \\
\text { contribuinte, fica descaracterizado o propósito de cobertura de risco (hedge) da operação. Nesse caso, para } \\
\text { fins de dedutibilidade na determinação do lucro real, impõe-se o reconhecimento das perdas apuradas em } \\
\text { operações de swap somente até o limite dos ganhos auferidos nas operações de mesma natureza. }\end{array}$ & - & Ausente & - & Não \\
\hline 18 & $\begin{array}{l}\mathrm{N}^{\mathrm{o}} 16- \\
15966\end{array}$ & $21 / 12 / 2007$ & $\begin{array}{l}\text { Cabe à defesa a prova dos fatos modificativos ou extintivos da pretensão fazendária, no caso a comprovação } \\
\text { de que a aquisição das opções flexíveis de venda de dólar foi efetuada com o objetivo de proteção contra } \\
\text { queda na taxa de câmbio. }\end{array}$ & - & Ausente & Ausente & Não \\
\hline 19 & $\begin{array}{l}\mathrm{N}^{\circ} 07- \\
14191\end{array}$ & $03 / 10 / 2008$ & $\begin{array}{l}\text { São dedutíveis na apuração do lucro real as perdas apuradas em contratos de swap hedge, segundo o regime de } \\
\text { competência. Exclusões de resultados nestas operações referentes a outros anos-calendário, que não o de } \\
\text { apuração, são indedutíveis. }\end{array}$ & - & Presente & - & Sim \\
\hline 20 & $\begin{array}{l}N^{\circ} 07- \\
17268\end{array}$ & $21 / 08 / 2009$ & $\begin{array}{l}\text { A dedutibilidade das perdas em operações de hedge, prevista em lei e limitado aos ganhos nas mesmas, não se } \\
\text { aplica as operações de hedge que visam à proteção dos elementos patrimoniais (art. 77, inciso V da Lei } \\
\text { 8.981/95). }\end{array}$ & - & - & Ausente & Não \\
\hline 21 & $\begin{array}{l}N^{\circ} 16- \\
23890\end{array}$ & $17 / 12 / 2009$ & $\begin{array}{l}\text { Os valores resultantes de operações de } s w a p \text { considerados dedutíveis pelo contribuinte devem ser } \\
\text { demonstrados de forma clara e inequívoca, acompanhados da respectiva documentação suporte, da } \\
\text { prova de seu registro, da comprovacão da finalidade e utilidade para a empresa, além da } \\
\text { compatibilidade com a proteção cambial necessária. }\end{array}$ & Ausente & Ausente & Ausente & Não \\
\hline \multirow[t]{2}{*}{22} & $\begin{array}{l}\mathrm{N}^{\circ} 16- \\
27743\end{array}$ & $11 / 11 / 2010$ & $\begin{array}{c}\text { Para que sejam consideradas dedutíveis as perdas com as operações de hedge, são indispensáveis as } \\
\text { apresentações dos documentos que deram origem às aplicações e que sejam demonstradas as devidas } \\
\text { contabilizações nos livros contábeis. }\end{array}$ & - & Ausente & - & Não \\
\hline & & & TOTAIS & 8 & 15 & 7 & \\
\hline
\end{tabular}

Fonte: Elaborada pelos autores, com base na análise de conteúdo das decisões da DRJ selecionadas na análise documental.

Rerista

Contemporinea de

Contabilidade 


\section{Conclusões}

Este trabalho investigou os fatores que levam a dissonâncias entre fisco e contribuinte a respeito da comprovação de ocorrência de hedge em operações financeiras, por meio de estudo de caso de autuação fiscal e análise documental de decisões administrativas.

$\mathrm{O}$ estudo de caso realizado corroborou a literatura nacional e internacional revisada acerca do tema no sentido da existência de discordâncias entre contribuintes e fisco federal, decorrentes da assimetria de informação especificamente no que se refere à comprovação das operações financeiras com o intuito de hedge, na medida em que não obstante a Companhia A estivesse sujeita a variações cambiais de seus passivos (contratos de financiamento internacional e pré-pagamento à exportação) e mesmo ativos (clientes a receber no exterior), bem como a variações de preço das principais commodities que comercializavam (açúcar e etanol), o fisco federal acabou por glosar as perdas financeiras apuradas pela empresa, tratando-as como se especulativas fossem.

Por outro lado, em decorrência da apresentação de documentos, planilhas e gráficos elaborados e juntados pela empresa em resposta à autuação físcal, bem como em decorrência do resultado positivo da diligência fiscal efetuada, conclui-se que a assimetria informacional existente fora reduzida, considerando o sucesso da empresa em primeira instância administrativa, corroborando os estudos revisados no sentido de esta tender a ser mais "técnica" em seus julgamentos.

Da mesma forma, a pesquisa documental realizada nas decisões de primeira instância das DRJ em todo o Brasil demonstram que a comprovação da natureza de hedge passa por questões gerenciais, tais como comprovação de que as operações financeiras praticadas pelo contribuinte eram necessárias, usuais e normais à atividade da companhia; contratuais, tais como a comprovação da existência de ativos e passivos a serem protegidos; e contábeis, tais como contabilização adequada e de acordo com o regime de competência.

Com base no estudo, portanto, verificou-se que são fatores de dissonância entre contribuinte e fisco federal, principalmente, a ausência:

(i) de normas legais e/ou administrativas claras relativas ao tema "comprovação de hedge" a serem seguidas pelos contribuintes e observadas pelas autoridades fiscais, as quais, a julgar pela análise individualizada do estudo de caso, não detêm de conhecimento técnico uniforme, do ponto de vista contábil e econômico, para lidar com operações financeiras com derivativos, na maioria dos casos de grande complexidade;

(ii) nas normas tributárias e contábeis de controles internos obrigatórios e específicos a serem utilizados pelas companhias com o intuito de demonstrar a eficácia do hedge das operações financeiras que praticam, na medida em que a contabilidade de hedge prevista no Pronunciamento Técnico CPC 38 somente será aplicada caso a própria companhia detenha indícios claros da existência de operações de hedge e objetos de hedge;

(iii) de demonstrativos padronizados a serem preenchidos e entregues ao Fisco, como é o caso das Fichas da Declaração de Informações Econômico-Fiscais da Pessoa Jurídica (DIPJ), entregue anualmente pelas pessoas jurídicas, na medida em que são apresentadas informações financeiras relativas a ativos, passivos, resultados, preços de transferência e outras informações de interesse do Fisco federal, dentre as quais atualmente não se incluem instrumentos financeiros derivativos e operações de hedge.

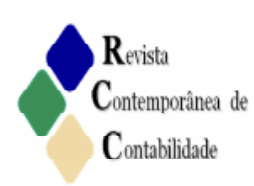


No que se refere ao item 3, tomando-se por base a DIPJ do exercício de 2012, referente ao ano-calendário de 2011, para fins da correta classificação da natureza das operações financeiras de determinada pessoa jurídica - se com a finalidade de hedge ou não -, uma nova ficha na Pasta Informações da DIPJ poderia ser criada, com informações a serem preenchidas pela empresa ou mesmo transportadas automaticamente das fichas relativas às Demonstrações Financeiras, no intuito de apresentar à RFB todas as informações relevantes e indispensáveis para a fiscalização da dedutibilidade das perdas e despesas financeiras dessa natureza.

Assim, as análises realizadas e os resultados encontrados apontam para a necessidade premente de alteração legislativa ou de evolução da legislação existente com vistas a dispor claramente das análises que poderão ser feitas pelo Fisco federal em caso de fiscalização das operações financeiras de hedge das companhias; forma de apresentação de informações e documentos por parte do contribuinte com vistas a comprovar a natureza de proteção de suas operações financeiras, afastando o risco da indedutibilidade das perdas; e, metodologias adicionais àquelas exigidas pela norma contábil (notadamente, CPC 38, CPC 39 e CPC 40) com vistas a reconhecer, mensurar e evidenciar contabilmente as operações financeiras com $\mathrm{o}$ intuito de hedge.

Por fim, este trabalho estabeleceu nova abordagem para a análise da assimetria de informação entre companhias brasileiras e Fisco federal, qual seja, o ponto de vista do contribuinte, denominado "agente" nessa relação, que tem interesses em evitar ou ao mesmo reduzir os bonding costs, levantando a necessidade de inovação normativa em busca de maior transparência e segurança jurídica das relações entre Fisco-contribuinte, na linha discutida por Lien e Metz (2001) e Mischler (1999).

\section{Referências}

BARDIN, L. Análise de conteúdo. 1. ed. Lisboa: Editora Edições 70, 2006.

BRASIL. Decreto n. 3.000, de 26 de março de 1999. Regulamenta a tributação, fiscalização, arrecadação e administração do Imposto sobre a Renda e Proventos de Qualquer Natureza. Diário Oficial da União, 29 mar. 1999.

BRASIL. Decreto-Lei n. 1.598, de 26 de dezembro de 1977. Altera a legislação do imposto sobre a renda. Diário Oficial da União, 27 dez. 1977.

BRASIL. Lei n. 6.404, de 15 de dezembro de 1976. Dispõe sobre as Sociedades por Ações. Diário Oficial da União, suplemento, 17 dez. 1976.

BRASIL. Lei n. 8.981, de 20 de janeiro de 1995. Altera a legislação tributária Federal e dá outras providências. Diário Oficial da União, 23 jan. 1995.

BRASIL. Lei n. 9.430, de 26 de dezembro de 1996. Dispõe sobre a legislação tributária federal, as contribuições para a seguridade social, o processo administrativo de consulta e dá outras providências. Diário Oficial da União, 30 dez. 1998. 
CAPELLETTO, L. R.; OLIVEIRA, J. L.; CARVALHO, L. N. Aspectos do hedge accounting não implementados no Brasil. Revista de Administração. São Paulo, vol. 42, n. 4, p. 511 523, out./nov./dez. 2007.

COMITÊ DE PRONUNCIAMENTOS CONTÁBEIS. Pronunciamento Técnico CPC 38. Instrumentos Financeiros: reconhecimento e mensuração. Correlação às Normas Internacionais de Contabilidade - IAS 39, 2 out. 2009. Disponível em: $<$ http://www.cpc.org.br/pdf/CPC_38.pdf $>$. Acesso: 25 ago. 2011.

COMMITTEE OF SPONSORING ORGANIZATIONS OF THE TREADWAY COMMISSION (COSO). Internal Control Issues in Derivatives Usage, 1996.

GRAHAM J. R.; ROGERS, D. A. Do Firms Hedge in Response to Tax Incentives? The Journal of Finance. v. 57 (LVII), n. 2, Abril 2002.

GUERRA, L. F. G.; GALDI, F. C. Determinantes para utilização de Hedge Accounting: uma escolha contábil. Revista de Educação e Pesquisa em Contabilidade (REPeC). v. 3, n. 2, 2009.

LAMEIRA, V. J.; FIGUEIREDO, A. C.; NESS JR., W. L. Hedge, redução de volatilidade dos lucros e o efeito sobre o imposto de renda das companhias brasileiras. Revista de

Contabilidade Financeira - USP, São Paulo, n. 38, p. 31-46, Maio/Ago. 2005.

LIEN, D.; METZ, M. Corporate Income Tax and Futures Hedging. Journal of Economics and Finance. vol. 25, n. 3, out. 2002.

LOPES, A. B; GALDI, F. C.; LIMA, I. S. Manual de contabilidade e tributação de instrumentos financeiros e derivativos (CPC 38, CPC 39, CPC 40, OCPC 3, IAS 39, IAS 32), Normas da Comissão de Valores Mobiliários, do Banco Central do Brasil e da Receita Federal do Brasil, 2. Ed., São Paulo: Atlas, 2011.

MARTINS, G. A. Manual para elaboração de monografias e dissertações. 3. ed. São Paulo: Atlas, 2002.

MILEVSKY, M. A.; PRISMAN, E. Z. Hedging and Pricing with Tax Law Uncertainty: Managing under an Arkansas Best Doctrine. The Quarterly Review of Economics and Finance. v. 39, n. 1, p. 147-168, 1999.

PEDWELL, K. Influence of accounting on tax court decisions: an empirical analysis. 2000. 186 f. Tese (Doutorado em Filosofia) - Faculdade de Administração - The University of Calgary, Alberta, Canadá.

PENTLAND, B. T.; CARLILE, P. Audit the taxpayer, not the return: tax auditing as an expression game. Accounting, Organizations and Society. Oxford, v. 21, nº 2/3, p. 269287, 1996. 
POHLMANN, M. C.; IUDÍCIBUS, S. Tributação e política tributária: uma abordagem interdisciplinar. São Paulo: Atlas, 2006.

SHACKELFORD, D. A.; SHEVLIN, T. Empirical tax research in accounting. Journal of Accounting and Economics 31, p. 321-387, 2001.

YIN, R. K. Estudo de Caso: planejamento e métodos, tradução Ana Thorell, revisão técnica Cláudio Damacena, 4. ed. Porto Alegre: Bookman, 2010. 